\title{
A review of the bioenergy potential of residual materials in Quebec
}

\author{
S. David ${ }^{1} \&$ N. Abatzoglou ${ }^{2}$ \\ ${ }^{1}$ Laboratoires Shermont Inc., Canada \\ ${ }^{2}$ Université de Sherbrook, Canada
}

\begin{abstract}
In Quebec more than 48\% of residual materials produced in 2006 throughout all societal activities have been disposed of finally in landfills. Despite of the government policies on 3Rs (Reduction, Reutilization, Recycling) and the total recovery objectives set-up, the total mass landfilled has increased by $120 \%$ over the last 10 years. Over the last 50 years, although the agricultural surface decreased by half, the number of pigs tripled. With an annual production of almost 8 million pigs, on a more than 400 out of a total of 1200 Quebec municipalities have a considerable surplus in liquid manure. The present work undertakes a review of these two growing problems-opportunities in Quebec and proposes alternative and sustainable solutions. Since the building and operation of experimental bioreactors (manure digesters) in some farms in Quebec, the anaerobic co-digestion of the rural and urban putrescible materials seems an interesting avenue. The development of a green energy vector by valorizing the so-produced biogas, would also contribute in decreasing the rejection of contaminants in the environment. In this work, only the biomass, resulting from the residential sector and the quantity of the liquid manure available in Quebec, is considered to calculate the bioenergy potential. The bioenergy output of the various methanisation processes is compared with that abroad, particularly in Europe. The available biomass in Quebec has been calculated based on available statistical data regarding the production of urban waste and manure. The review shows that this bioenergy vector technology is sustainable and that its commercialization can be profitable at a cost not higher than that of disposal in landfills.
\end{abstract}

Keywords: biomass, organic waste, anaerobic methanisation, bioreactor, codigestion, green energy, bioenergy. 


\section{Introduction}

It is well established that actually the prices of the majority of the goods and services do not integrate the real social and environmental cost. This is ecologically unacceptable. This is mainly due to the fact that the markets, in their current structure, are unaware of the limits of the natural processes. In nature, all residual matter generated by a living organism is used as a resource by another; this ensures the natural recycling of all used resources. The challenge of our society is to reproduce this process in its economy.

The putrescible matter is one of the principal causes of contamination in the places of disposal. At the landfills, the anaerobic fermentation generates greenhouse gases (GHG). The organic compounds released by this fermentation migrate with water of leaching (leachates) and can contaminate surface as well as subsoil waters and aquifers thus, rendering them unsuitable to human consumption and to the surrounding biotopes. The recovery of the putrescible matter at ends of valorization reduces the polluting load and the GHG emissions while providing us with bioenergy and valued products (i.e. compost). The reduction of residual materials which end up in landfills is a positive element on the economy and the environment for a variety of reasons, including the reduction of the transport of these residual materials.

The hog farms activities and the resulting manure spreading for fertilizing purposes contribute considerably to the release of ammonia emissions, the increase of the phosphorous content in the soil and the pathogenic organisms in the environment. The emissions of ammonia contribute to the GHG as well as to an imbalance of the nutritive elements in the ecosystems, including surface water. Long-term liquid manure spreading in Quebec, based on directives inspired by soil nitrogen enrichment, led to an excess of phosphorus. Moreover, spreading of the liquid manure also increases the water-soluble phosphorus concentrations, which causes direct eutrophication conditions in surface waters. Currently the farm-byfarm approach stipulated in 2002 by the Law on the agricultural production led to a serious problem. Indeed, instead of calculating the rate of available phosphorus by catchment area, the quantity of phosphorus surplus is calculated based on the surface of the so-fertilized soil. This approach does not consider the type of soil, the zones easily flooded, the antibiotics present in the liquid manures and the initial quality of the surface waters (lakes and rivers) near the ground of spreading. These factors can have direct repercussions for certain rivers and more sensitive underground sheets of water. In an effort to minimize the harmful effects on the environment by the actual residual materials disposal and by the management of the liquid manure, this review tries to establish if methanisation of the organic residues and the liquid manure can be a sustainable solution.

\section{Solid waste management in Quebec}

In Quebec, based on data of 2006, only half of the materials which may undergo beneficiation were recovered. The landfill of the putrescible materials, the spreading of the animal manure and their storage are not sustainable solutions. 
These practices contribute to higher management costs, to GHG increase and other environmental nuisances including the direct effect on the natural resources availability.

\subsection{The waste recycling in Quebec}

Since 1989, the year of the publication of the Integrated Solid Waste Management Policy, Quebec made a significant step in the direction of sustainable development. However, 17 years later, according to a Recyc-Quebec [1] assessment in 2006, Quebec recovers hardly $52 \%$ of its residual materials. More specifically, inasmuch as organic matter is concerned, its collection is at present under development in Quebec. This collection comprises the green residues, such as the branches, grass and sheets as well as the remainders of table. There are currently 44 composting installations in Quebec. Moreover, the cities or municipalities of Laval, Victoriaville, Lachute, Saint-Donat, Rawdon and the Island-of-the-Madeleine, have successful organic matter collection activities. However, the rate of recovery of all putrescible residual materials is as low as $8 \%$ ! In 2006, the quantity of recovered organic matter rose to 0.36 million tons on a potential of approximately 4.5 million tons. It should be noted that the objectives of the Policy are expressed according to the potential which may undergo beneficiation. It is estimated that $85 \%$ to $90 \%$ of the residual materials of the various branches of activity have a potential of being valuably recovered. Recyc-Quebec announced in 2006 that nearly 13 million tons of residual materials are generated annually in Quebec. As Quebec's population in 2006 was 7.651 million inhabitants, the total rate of production of residual matters per capita and year is estimated at 1.69 tons, including industries, trade activities and institutions. A noticeable fact is that, in 2006, the rate of final disposal of these materials through landfill and incineration was estimated at $880 \mathrm{~kg} / \mathrm{year} / \mathrm{inh}$ abitant, whereas ten years earlier, this quantity was lower; $740 \mathrm{~kg} / \mathrm{year} / \mathrm{habitant}$ in 1996 . Thus, the average inhabitant of Quebec, including industrial, trade, construction, restoration/demolition and institutions activities, as well as the municipalities, eliminated in 2006, $875 \mathrm{~kg} /$ year/inhabitant and recovered $940 \mathrm{~kg} /$ year/inhabitant.

\subsection{The compostable material coming from the municipal residential sector}

The municipal sector generates an average of $23 \% \mathrm{w} / \mathrm{w}$ of Quebec's residual materials. Thus, in 2006, the municipal sector generated 3.015 million tons. This represents an average of $400 \mathrm{~kg} /$ year/inhabitant. Although $95 \%$ of these materials are theoretically recyclable, only $31 \%$ of them were recovered. Thus, 255 $\mathrm{kg} /$ year/inhabitant were disposed of finally in landfills or incinerated. The putrescible materials represent $44 \%$ of the total 3.015 million tons generated annually. This is 1.327 million tons of compostable organic material per year which may undergo beneficiation. The available statistical data give us the information that only 0.110 million organic tons of materials were recovered in 2006. Table 1 presents Quebec's population by administrative areas, according to 
the 2001 census, and an estimation of the quantity of putrescible materials available by areas. This estimation was done by assuming that the residual material generation is geographically uniform in Quebec. Globally it is easy to calculate that the remaining available compostable material is $183 \mathrm{~kg} / \mathrm{year} / \mathrm{inh}$ habitant.

Table 1: Generation of organic compostable materials by the residential sector in the different administrative regions in Quebec.

\begin{tabular}{|l|c|c|}
\hline Administrative regions & Population & $\begin{array}{c}\text { Organic compostable } \\
\text { materials (tons/year) }\end{array}$ \\
\hline Bas-Saint-Laurent & 200,630 & 36,715 \\
\hline Saguenay-Lac-Saint-Jean & 278,279 & 50,925 \\
\hline Capitale-Nationale & 638,917 & 116,922 \\
\hline Mauricie & 255,268 & 46,714 \\
\hline Estrie & 285,613 & 52,267 \\
\hline Montréal & $1,812,723$ & 331,728 \\
\hline Outaouais & 315,546 & 57,745 \\
\hline Abitibi-Témiscamingue & 146,097 & 26,736 \\
\hline Côte-Nord & 97,766 & 17,891 \\
\hline Nord-du-Québec & 38,575 & 7,059 \\
\hline Gaspésie-îles-de-la- & 96,924 & 17,737 \\
Madeleine & 383,376 & 70,159 \\
\hline Chaudière-Appalaches & 343,005 & 62,770 \\
\hline Laval & 388,495 & 71,095 \\
\hline Lanaudière & 461,366 & 84,430 \\
\hline Laurentides & $1,276,397$ & 233,581 \\
\hline Montérégie & 218,502 & 39,986 \\
\hline Centre-du-Québec & $7,237,479$ & $1,324,460$ \\
\hline \multicolumn{1}{c|}{ Total: } & & \\
\hline
\end{tabular}

\subsection{The landfill sites}

The average maintenance costs of the landfill sites is approximately $65 \mathrm{cnd} \$ /$ ton. The law "Règlement sur l'enfouissement et l'incinération de matières résiduelles" (c. Q-2, r.6.02) adds an additional fee (tax) of $10.22 \mathrm{cnd} \$ /$ ton. On this basis, approximately 504 million cnd $\$$ have been spent in Quebec only in 2006 for the landfill of the residual materials. These numbers do not include the transport cost. Moreover, these costs do not contain the management of the animal manure, mining, papermills and sawmills residues, the contaminated soils as well as all materials characterized as dangerous and biomedical. According to the "Règlement sur l'enfouissement et l'incinération de matières résiduelles" (c. Q-2, r.6.02), a soil of minimal thickness of $30 \mathrm{~cm}$ must cover each day the landfilled residual materials in order to protect it from vermin and biogas spreading. 


\subsection{The porcine industry}

In June 2002, Quebec adopted the law "Règlement sur les exploitations agricoles" (REA); this law is aimed at agricultural activities within the context of the sustainable development. Its main objective is to have the farmers being more concerned about the management of the animal manure and other fertilizing matters, more particularly phosphorus. The phosphorus assessment, required by the REA, is one of the main tools of this law. The farms having a surplus of fertilizing potential will be under the obligation, according to REA, to reach a balance between the capacity of the soil to receive phosphorus and the quantities of manure to be spread out in these lands. For some of them, the only solution enabling them to reach this balance will be the treatment of the liquid manure. In Quebec, the number of farms passed from 135,000 in 1951 to 35,000 in 1996. Moreover, the agricultural surfaces decreased by about $50 \%$ since 1951 ; from 3.4 to 1.9 million hectares. However, during the same period the number of pigs has tripled. The annual volume of production should not be confused with the number of pigs in inventory on the porcine exploitations during the year. Quebec counted approximately 3.9 million pigs in inventory in 2004 and 4.2 million in 2006. There were 4,097 producers of pigs in 2004 and 4,309 in 2003, a fall of 212 in one year. Such a geographically uniform space reduction, in one year only, accompanied by a production increase, can be explained by the increase of the activities of the existing integrators. Indeed, since the total annual volume of animal manure appears constant in Quebec (at approximately 32 million $\mathrm{m}^{3}$ of animal manure, of which approximately 10 million $\mathrm{m}^{3}$ of liquid manure), the farms have to manage an increasingly larger volume of manure. The quantity of liquid manure was multiplied by a factor of 90 between 1951 and 2001! Approximately $60 \%$ of the hog farms must have to establish local agreements for manure land spreading, because they do not possess enough arable land to respect the law. According to the Quebec Ministry of the Environment, more than 400 municipalities out of 1,200 are in theoretical surplus of manure and/or liquid manure. Table 2 presents the quantity of liquid manures produced in Quebec.

In March 2006, a refundable temporary tax credit was founded for the acquisition of installations for the treatment of pig liquid manure. This credit accounts for $30 \%$ of the acquisition and the installation costs of such a system of manure treatment; a maximum of $200,000 \mathrm{cnd} \$$ is allocated by agricultural establishment. Only porcine companies, which do not qualify or make use of the provisions of chapter 6 of the program Premium-Green, qualify for this tax credit. All technologies of liquid manure treatment decrease the volume of the final disposal; this means that all fertilizing elements are concentrated in smaller volumes. They also contribute to reducing the odours associated with the management of liquid manures. Denmark is a pioneer in the management of livestock wastes and the optimal use of the nutritive elements contained in them. Several successful programs have directly risen from Denmark's agricultural policy: for example, the installation of $\mathrm{V}$ and $\mathrm{W}$ shaped sludge pits leads to a reduction of the ammonia evaporation by as high as $25 \%$, while the cooling of the sludge in the pits results in an additional reduction of $20 \%$. 
Table 2: Manure production by region in Quebec.

\begin{tabular}{|l|r|r|}
\hline \multicolumn{1}{|c|}{ Administrative regions } & $\begin{array}{c}\text { Number of pigs [2] } \\
\text { (2006) }\end{array}$ & \multicolumn{1}{c|}{$\begin{array}{c}\text { Manure } \\
\text { (tons/year) }\end{array}$} \\
\hline \hline Bas-Saint-Laurent & 153,459 & 475,723 \\
\hline Saguenay-Lac-Saint-Jean & 16,954 & 52,557 \\
\hline Capitale-Nationale & 97,433 & 302,042 \\
\hline Mauricie & 142,945 & 443,130 \\
\hline Estrie & 249,363 & 773,025 \\
\hline Montréal & n.d. & n.d. \\
\hline Outaouais & 365 & 1,132 \\
\hline Abitibi-Témiscamingue & n.d. & n.d. \\
\hline Côte-Nord & n.d. & n.d. \\
\hline Nord-du-Québec & n.d. & n.d. \\
\hline Gaspésie-îles-de-la-Madeleine & n.d. & n.d. \\
\hline Chaudière-Appalaches & $1,296,635$ & $4,019,569$ \\
\hline Laval & n.d. & n.d. \\
\hline Lanaudière & 274,458 & 850,820 \\
\hline Laurentides & 31,178 & 96,652 \\
\hline Montérégie & $1,420,141$ & $4,402,437$ \\
\hline Centre-du-Québec & 519,365 & $1,610,032$ \\
\hline & $4,202,296$ & $13,027,119$ \\
\hline
\end{tabular}

\subsection{The methanisation industry}

The management of the organic residues is not only one a concern in Quebec. In Europe there are already biogas production facilities from the anaerobic fermentation of organic residues. In Quebec, the final disposal of the majority of organic compostable material is done systematically as follows:

$>$ Incineration for the municipal wastewater treatment sludge;

$>$ Landfill disposal for the residential (table) residues;

$>$ Composting for the green residues;

$>$ Land spreading for the animal manure.

\subsubsection{The legal context for the energy in Quebec}

In Canada, energy is under provincial jurisdiction and the law provisions vary considerably from one province to another. The new strict regulations covering the management of waste and the high costs of energy seem to boost the interest in all provinces. In fact, the province of Ontario has recently put in application a regulation establishing the price of $0.11 \$ / \mathrm{kWh}(0.14 \$ / \mathrm{kWh}$ at the peak hours) for green electricity. This makes biogas more attractive to the Ontario's farmers. Ontario and Quebec are the only provinces to offer subsidies to those who install and operate biogas production systems. In fact, Quebec pays $70 \%$ of the costs incurred to install a manure handling system (maximum of 200,000\$). The Ontarian producers can obtain a subsidy of up to $60,000 \$$ for a system of manure treatment and storage capacity in the farm. Currently in Quebec, no law exists covering specifically the production of biogas. However, some regulations like the one covering the waste elimination activities (landfill and incineration) and the 
production of electricity contain some clauses on biogases. For example, the landfills must be appropriately sealed in order to avoid the migration of biogases through the air or the subsoil. Thus, biogases from these sites must be collected and, in the absence of energetic exploitation, this biogas must be burned safely and in accordance with the law for the atmospheric quality preservation. It is rather obvious that, without a specific regulation covering the production of biogas, and which defined clearly all constraints to be respected, it is difficult to establish a long-term biogas production system. However, according to the article 22 of Quebec's Law on the Environmental Quality (LQE), a certificate of authorization is requested for the establishment of a residues management activity. To produce such a certificate, an Environmental Impact Assessment study must be deposited to the Ministry of the Sustainable Development, the Environment and Parks (MDDEP). In the case of the construction of a high capacity power station, the project team has to deposit the preliminary draft of such a study to the Office of the Public Hearings (Bureau d'audiences publiques sur l'environnement - BAPE), such as defined in article 31.1 of the LQE. In Canada, under the article 5 of the Canadian Law on the environment, an environmental assessment is requested also for having the project authorized. If the project contributes in establishing more sustainable management activities, the Ministry of the Natural Resources Canada could even provide financial assistance to the project in order to help respecting the Environmental Law provisions.

Moreover, the Federal Government brought modifications to the rates of the deduction for goods amortization (DGA). The maximum rate of DGA for each type of redeemable good is fixed in the Law covering the field of income tax payment. The rate of DGA applicable to certain high efficiency cogeneration units and renewable energy production passes from $30 \%$ (rate of category 43.1 ) to $50 \%$ because of the inclusion of these goods in the new category 43.2. To qualify for this new increased rate, the material used in building such a unit must generally be new and be acquired after February 22, 2005 and before 2012. This new rate will also apply to any biogas production material and district energy distribution networks which use efficient cogeneration technology after February 22, 2005 and before 2012 .

\subsubsection{Biogas production}

Methanisation represents a possible sustainable solution for the recycling of organic matter. All organic materials can produce biogas: i.e. animal dejections, fruits, vegetables, remainders of slaughter-house, rejections of dairy, brewery, distilling. The organic matter rich in fibre like the grass, sheets and wood is however difficult to digest and are not recommended to use as source of biogas. The biogas composition depends upon the nature of the treated waste and the treatment conditions which depend largely on the local climate. The average composition of biogas is $60 \%$ methane $\left(\mathrm{CH}_{4}\right)$ and $40 \%$ carbon dioxide $\left(\mathrm{CO}_{2}\right)$. The bioreactor is an anaerobic tank where organic matter is introduced and the temperature has to be maintained at an appropriate level depending upon the nature and the activity of the anaerobic digestion microorganisms. Under the selected conditions, anaerobic bacteria use the organic matter as feed to multiply 
and produce biogas as a result of their metabolism. The quantity of organic matter which exits the bioreactor is equal to that at the entrance minus the produced biogas. The digested organic matter is practically odourless, has a high fertilizing value, it is less polluting and reduced in organic load $\left(\mathrm{DBO}_{5}\right)$. The exiting solid/liquid mixture can be separated; the solid muddy part (sludge) can be composted and the liquid part can be used directly as a fertilizer or treated and disposed of safely according to the existing regulations.

The collection and energetic exploitation of the biogas produced during the anaerobic methanisation decreases the GES by a factor of just as 20 . Since the digestion conditions are better controlled within a bioreactor, the total quantity of biogas per unit of organic matter extracted from a bioreactor is higher than that extracted from a landfill site. A bioreactor is 3 to 10 times more energy efficient than landfill. The quantity of biogas which can be extracted from the organic matter also depends on the type of organic residues and the performance of the bioreactor. Therefore, the production of biogas varies from 20 to $800 \mathrm{~m}^{3}$ per ton of organic material. Each $\mathrm{m}^{3}$ of biogas contains the equivalent of $6 \mathrm{kWh}$ of energy. However the conversion of biogas into electricity by an electric generator produces $2 \mathrm{kWh}_{\mathrm{e}}$; the other $4 \mathrm{kWh}$ is dissipated in the form of heat and at least $75 \%$ of this which can be recovered and used for thermal energy needs. The capital investment for a bioreactor is relatively high [3]. The payback period for such an investment is estimated [4] at 7-10 years and it is due to the value of the biogas and more precisely its value as an electrical and/or thermal energy vector. Regarding the biogas as an energy vector, three uses are tested industrially: (a) combustion in a boiler for heat generation; (b) fuel of internal combustion engines for the production of electricity or for car motors and (c) in cogeneration for the simultaneous production of heat and electricity.

The treatment by methanisation of a tone of agricultural organic matter produces $500 \mathrm{~m}^{3}$ of methane at standard conditions. The methanisation by anaerobic digestion utilizes the organic matter which is most easily digestible, that is $30-80 \%$ of the oven dry organic material. Besides, this is the part which generates organic pollution, unpleasant odours and biogas. The part remaining after methanisation $(20-70 \%)$ can be used as fertilizer in agriculture. The methanisation of wastewater treatment plants sludge as well as all putrescible domestic (residential) and industrial waste reduced their quantity by up to $35 \%$. A ton of these organic residues generates up to $175 \mathrm{~m}^{3}$ of biogas. A landfill recovers an average of $100 \mathrm{~m}^{3}$ of methane per ton of treated waste, whereas in agriculture, a ton of manure produces in 90 days approximately $60 \mathrm{~m}^{3}$ of biogas containing $55 \%$ of methane.

The oldest and more mature methanisation technology through anaerobic digestion is that of "the infinitely mixed" bioreactor in whom mixing is ensured hydraulically or more frequently by biogas recirculation. This type of bioreactor is generally operated with mesophilic organisms towards $35^{\circ} \mathrm{C}$. In the last years several technological novelties have been proposed and improved the efficiency of this type of bioreactor in such a way that streams like domestic organic materials, which are generally more complex than manure, could be received and methanized as well. Degrémont, for example, has proposed the upstream use of a 
"hydropulpor", a metal tank equipped with a central propeller which lyses the vegetable cells and puts the organic matter in full suspension in the recycle stream of the process (proceeded BTA). In this process the inorganic matters which could enter the unit (e.g. plastic, textile) float on the surface and are recovered by a hydraulic comb; the heavy mineral elements (e.g. glass, stones, bones) decant and are extracted by the bottom. The thus produced liquid pulp passes then in a hydrocyclone which removes the heavy fine and abrasive particles like sand. In Germany and Austria, bioreactors appeared in ovoid forms [5]. This form has a smaller footprint per volume, allows a more homogeneous and regular mixing thus reducing the dead zones or those of preferential fermentation and facilitates decantation. The second generation bioreactors use the technology of the fixed cells or "anaerobic filter". This technology allows a quasi-continuous flow bioreactor operation because the bacteria are fixed in a preselected support and they are not entrained by the treated liquid flow.

In France, the process suggested by Proserpol, comprises a support made up of plastic rings in bulk and the injection of the feed is carried out by the top of the bioreactor all over and through the bacterial stabilization rings. In the Netherlands, the process UASB (Upflow Anaerobic Sludge Blanket) was introduced [found in 5] in which the support is biological and flow is ascending. Compared to the old technique, this technology has the advantage of being much faster (a few hours or a few days instead of two weeks). It is possible to still speed up the process by adopting the thermophilic fermentation, which multiplies the productivity by a factor of 4-10 and produces a biogas richer in methane (up to about $80 \% \mathrm{v} \mathrm{CH} \mathrm{CH}_{4}$ ). For the hog farms manure, the process must proceed in two stages, the preliminary acidification, then methanisation, which call upon families of different bacteria, which must, thus, be held in distinct tanks. The Tilburg bioreactors in the Netherlands (1994, 52,000 tons/year) and that of Engelskirchen in Germany (1998, 35,000 tons/year), are fed only with organic materials coming from domestic waste. The methane produced in Tilburg's bioreactors is introduced into the gas network of the municipality for domestic use. The Engelskirchen's biogas is used for the production of electricity. Thanks to a sorting at the source, both produce a compost of high quality. During its high output operation, the factory of Tilburg produces 4 million $\mathrm{m}^{3}$ of biogas per year. This biogas contains $56 \% \mathrm{CH}_{4}$, very small amounts of hydrogen sulphide, and 31,000 tons/year of organic soil conditioner which may undergo beneficiation in agriculture. The idea of a selective and centralized co-digestion of agricultural biomasses was born in Denmark and was applied since 1988 thanks to the support of the government. It consists in collecting in the vicinity of the manures production sites the existing domestic and/or industrial organic waste, sludge from wastewater treatment stations and methanize them together. The economic assessment of the operation is mitigated. With a starting investment of 8 million $\$$ and operating costs of $600,000 \$ /$ an, the payback period has been $8-10$ years thanks to the subsidy of 3 million $\$$ granted by the Danish Ministry of Energy. The main part of the incomes comes from the sale of biogas (800,000 to 1,000,000 \$/year) and from the waste management tipping fee which the industrialists pay to get rid of their waste (approximately 200,000 \$/year). 


\section{Methanization in Quebec?}

Methanization represents a complement of activity for the farmers, who can develop economically and energetically the liquid manure and even the organic part of the domestic residues. Methanisation is synonymous with energetic autonomy for the biogas producers. While bringing an energetic and ecological response to the problem of the treatment of the liquid manures and organic residues, methanization is an activity of depollution and an alternative to landfill.

The environmental cost of the deterioration of nature by hog farming must be taken into account in the market price of the pig. This cost can be attenuated by agreements between eco-energy the hog farms; thus, hog farms manure can be a feedstock for eco-energy farms producing compost and biogas as an energy vector. Only the cost of transport would be the responsibility of the producer, whereas the eco-energy farms would recover and market the green energy. Producers' cooperatives can also contribute financially in order to install common bigger bioreactors.

As explained below, the establishment of a "two ways" selective waste sorting at the source and pick-up could be a sustainable solution. Our residues would be split in putrescible organic and non-putrescible materials. This strategy would allow recovering nearly $95 \%$ of all residual matters in the domestic sector. The codigestion of putrescible organic residues and liquid manure would be beneficial to both the agricultural and municipal sectors. The accessibility of this putrescible resource was established by administrative regions in Quebec. The density of the population is not an important factor, since in rural as well as in urban areas, the transport of the organic matter to an eco-energy farm is at least as easy as in any existing landfill site. The only element which differentiates the administrative regions between themselves is that certain among them do not have or have few hog farms, which would be favourable to install and operate bioreactors because of their characteristics as large urban number of eco-energy farms is required per administrative region and potential revenues. However, due to the proximity of the territories of Montérégie and Lanaudière, the administrative areas of Montreal and Laval, which are such urban centers, could easily transport their organic residues in bioreactors operated in these two other areas.

Table 3 presents the energetic potential of the combined domestic putrescible organic material and the manure in Quebec. Each ton of organic matter was estimated as having a potential of production of $100 \mathrm{~m}^{3}$ of biogas. This is very conservative because it represents the equivalent of the production in a landfill which is at least 3 times lower than that in a bioreactor. The energy which can be recovered by biogas, was evaluated to $2 \mathrm{kWh} / \mathrm{m}^{3}$. Thus, according to table 3 , an energy potential of 2,844,656,000 $\mathrm{kWh}$ is available in Quebec. Considering that in Quebec, a one-family residence consumes $17,000 \mathrm{kWh}$ annually, the energy needs of about 167,000 houses can be covered. Since the cost of residential electricity in Quebec is approximately $0.05 \mathrm{cnd} \$ / \mathrm{kWh}$, the green energy worth is roughly 142 million of cnd\$. 


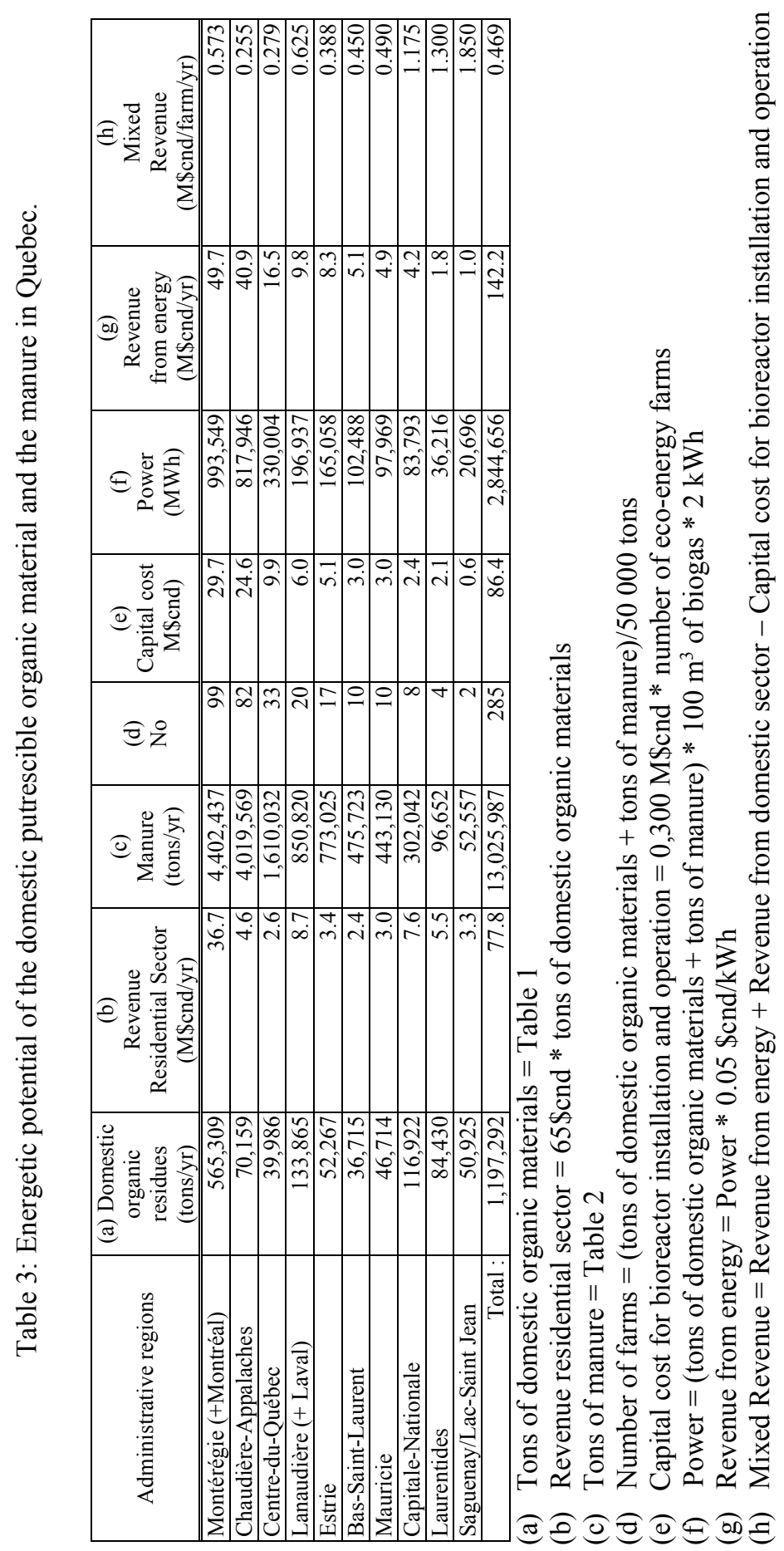


The number of eco-energy farms was evaluated according to a self-capacity of 50,000 tons of organic matter per year. The cost for the establishment of such a farm was estimated at 0.3 million cnd\$. It should be noted that the actual cost of the management of the organic matter coming from the domestic (residential) sector is equal to $90 \%$ of the capital cost of the installation of the 285 bioreactors necessary for methanizing annually the 14 million tons of the available putrescible materials (domestic + manure). Considering the contribution of income of the residential sector, only the areas of the Boiler-Appalachian Mountains and Center-of-Quebec, do not offer an income higher than the cost of establishment of an eco-energy farm.

\section{Conclusion}

The establishment of a two ways (putrescible and non-putrescible) selective sorting and pick-up of the domestic residues in Quebec would increase the rate of recovery of all the residual matters. The non-putrescible matters can be recycled up to $95 \%$, whereas the organic matter can be used as a renewable energy vector. The only problem comes from the green residues (grass, sheets, paper and paperboard) which contain a high percentage of non-easily digestible collection which is already established in some municipalities (i.e. Victoriaville, Sherbrooke). A good sorting of the putrescibles at the source (residential) is important because the efficiency of the methanization bioreactors and the quality of the resulting compost are strong function of the feedstock quality. The existence of incentives and the appropriate enforcement of a regulation establishing an obligation to treat the manure of all hog farms in eco-energy farms using bioreactors would also contribute to the reduction of contaminants in the environment. All putrescible matters (domestic putrescible organic materials and liquid manure) can be treated (methanized) in eco-energy farms, equipped codigestion bioreactors. As it is well established that the ideal operation conditions of the anaerobic digestion of these two distinct families of putrescible organic materials are not the same, some additional fundamental and applied research is necessary to have a sustainable operation. The existence of two parallel bioreactors might be an appropriate solution since it is known that different bacterial populations are needed. By considering only the income received from the production of green energy, the payback period of a bioreactor at an average Quebec hog farm is approximately 10 years. As for the eco-energy farms, they could require higher initial investments because of the combined feed complexity. These additional costs can be set-off by the perception of the equivalent landfill disposal tipping fee which in Quebec is in average 65\$/ton.

If this scenario becomes a reality, nearly 13 million tons of liquid manure and 1 million tons of putrescible domestic organic materials produced annually in Quebec could become a source of green, renewable energy in a sustainable development context, without any economic or social sacrifice. 


\section{Acknowledgements}

The contribution of Steve Boivin, Eng. and Richard Royer, Eng. of Bio-Terre Systems Inc., (150, rue Vimy, Sherbrooke, Québec, Canada, J1J 3M7) is gratefully acknowledged.

\section{References}

[1] Recyc-Québec, Bilan 2006 de la gestion des matières résiduelles au Québec, Bibliothèque et Archives nationales du Québec, 2007.

[2] Institut de la statistique du Québec, Inventaire de fin de semestre de porcs, par région administrative, Québec 2005-2006, Gouvernement du Québec, 2007.

[3] Électrigaz, Le biogaz est une énergie renouvelable issue de la décomposition naturelle de la matière organique par des bactéries anaérobiques. 2007. http://www.electrigaz.com

[4] Électrigaz, Le biogaz est une énergie renouvelable issue de la décomposition naturelle de la matière organique par des bactéries anaérobiques. 2007. http://www.electrigaz.com

[5] Énergie Plus, Rapport, études France, 2007. http://www.energie-plus.com 